\title{
KEEFEKTIFAN PENDEKATAN PROSES \\ DAN PENDEKATAN GENRE TERHADAP KEMAMPUAN MENULIS KARANGAN ARGUMENTASI SISWA SMA
}

\author{
Agnes Apryliana \\ Universitas Muhadi Setiabudi \\ agnes_andini@yahoo.com
}

\begin{abstract}
ABSTRAK
Artikel ini berkaitan dengan kemampuan menulis karangan argumentasi siswa SMA kelas X di Kabupaten Banyumas. Rumusan masalahnya adalah adakah perbedaan keefektifan penggunaan pendekatan proses dan pendekatan genre dalam pembelajaran menulis karangan argumentasi, tujuannya adalah untuk mengetahui perbedaan keefektifan dalam penggunaan pendekatan proses dan pendekatan genre terhadap kegiatan pembelajaran menulis karangan argumentasi siswa SMA kelas X di Kabupaten Banyumas. Desain ekperimen yang digunakan dalam penelitian ini adalah rendomized pre-tes-posttest control group design. Teknik pengambilan sampel menggunakan teknik sampel acak berlapis. Metode pengambilan data yang digunakan adalah tes kemampuan menulis karangan argumentasi. Teknik analisis data yang digunakan adalah uji-t dan ANAVA. Hasil penelitian menunjukkan bahwa ada perbedaan yang signifikan terhadap penggunaan pendekatan proses dan pendekatan genre dalam pembelajaran menulis karangan argumentasi. Pendekatan genre lebih efektif dibandingkan dengan pendekatan proses.
\end{abstract}

Kata Kunci: pendekatan proses, pendekatan genre, karangan argumentasi

\section{THE EFFECTIVENESS OF PROCESS AND GENRE APPROACH ON ARGUMENTATION WRITING ABILITIES OF THE CLASSX SENIOR HIGH SCHOOLS}

\begin{abstract}
This article is concerned with the ability of high school students write essays arguments of class $\mathrm{X}$ in the District Banyumas. The formulation of the problem is how the effectiveness of the process approach and genre approach in teaching essay writing argumentation, the goal was to determine differences in the effectiveness of the use of the process approach and genre approach to learning activities argumentation high school students write essays in class $\mathrm{X}$ in Banyumas. Experimental design used in this study is rendomized pre-test-posttest control group design. The sampling technique using stratified random sampling techniques. The data collection method by testing the ability to write essays of argumentation. Data analysis technique used t-test and ANOVA. The results showed that there were significant differences on the use of the process approach and genre approach in learning to write essays of argumentation. Genre approach is more effective than the approach of the process.
\end{abstract}

Keywords: process approach, genre approach, argument essay

\section{PENDAHULUAN}

Menulis menjadi kegiatan yang selalu dilakukan oleh setiap manusia. Oleh karena itu, menulis menjadi salah satu kompetesi penting yang harus dikuasai oleh peserta didik. Menulis menjadi kegiatan kompleks yang menuntut sebuah pemikiran dan kreativitas tinggi dari seorang penulis. Pembelajaran menulis diharapkan dapat memberikan hasil tulisan yang mampu memberikan sumbangsih untuk menyelesaikan berbagai permasalahan di masyarakat. Kegiatan menulis menjadi sangat penting untuk mendukung kretaivitas dan eksistensi seseorang dalam bidang ilmu yang dimilikinya. Menulis 
merupakan salah satu dari keempat keterampilan berbahasa yang dipergunakan untuk berkomunikasi secara tidak langsung dengan orang lain. Menulis menjadi suatu kegiatan produktif dan ekspresif. Dalam kegiatan menulis, penulis haruslah terampil memanfaatkan kosakata, tata bahasa, sturktur penulisan, penulis harus untuk menentukan fungsi dan tujuan dari karangan yang ditulisnya.

Dalam kehidupan modern saat ini, keterampilan menulis sangatlah dibutuhkan. Setiap orang tidak dapat terlepas dari kegiatan tulis menulis. Hyland (2004: xv) menyebutkan bahwa menulis adalah kemampuan yang sangat penting untuk dimiliki oleh setiap orang.Oleh karena itu, guru perlu menyampaikan materi atau pengetahuan tentang menulis kepada para siswanya. Menulis sering dianggap sebagai salah satu aspek yang paling menantang dari pembelajaran bahasa kedua dan banyak peserta didik yang mengalami kesulitan dalam menyampaikan gagasan kedalam bentuk tertulis. Berasal dari fakta tersebut bahwa penulis (peserta didik) harus memahami struktur dan penggunaan bahasa dari setiap jenis teks yang berbeda (Hyland, 2004: 10). Selain itu, peserta didik masih mengalami kesulitan untuk mampu menulis secara kohesif sesuai dengan konvensi dari konteks akademik.

Kegiatan menulis menjadi sangat penting untuk dipelajari dan dikembangkan terutama dalam bidang keilmuan yang dimiliki oleh seseorang. Oleh karena itu, pembelajaran menulis di sekolah menjadi sangat penting untuk diajarkan kepada para siswa. Kemampuan menulis siswa Indonesia yang kurangdibuktikan dengan hasil penelitian yang dilakukan oleh PIRLS pada tahun 2011. Hasil riset yang dilakukan oleh PIRLS menunjukkan posisi kemampuan siswa Indonesia berada pada urutan ke 42 dari 45 negara dengan skor 428 (Kemendiknas, 2011). Kenyataan lain yang timbul dalam pelaksanaan pembelajaran di kelas menunjukkan para guru khususnya pada mata pelajaran bahasa Indonesia masih menggunakan metode oral atau metode ceramah. Guru mengenalkan kegiatan menulis hanya sebatas pengertian dan jenisjenis karangan tanpa memberikan kesempatan kepada siswa untuk mempraktikan teori yang telah mereka pelajari. Guru masih menjadi pu- sat pembelajaran. Hal ini yang menyebabkan kegiatan pembelajaran di kelas bersifat pasif. Siswa kurang berperan aktif dan jarang dijumpai keaktifan seperti berdiskusi, bertanya, ataupun praktik menulis terutama dalam menulis karangan argumentasi.

Kenyataan tersebut menimbulkan ketidakmampuan para siswa dalam memproduksi tulisan. Siswa mengalami kesulitan dalam mengungkapkan gagasan atau ide-ide mereka, siswa mengalami kebuntuan setiap kali menulis sebuah karangan terutama pada jenis karangan argumentasi yang sangat menuntut berpikir kritis dan memberikan komentar terhadap suatu topik yang akan dijadikan tulisan mereka. Keadaan ini berpengaruh terhadap kemampuan para siswa untuk mengemukakan pendapatnya dalam bentuk tertulis. Pada dasarnya menulis adalah kegiatan berpikir kritis dan produktif menjadi tidak berjalan dengan semestinya. Mulai dari KBK, KTSP, hingga Kurikulum 2013 (K-13) pada Sekolah Menengah Atasmenulis menjadi salah satu kompetensi dasar yang harus diajarkan dan dikuasai oleh peserta didik dalam mata pelajaran bahasa Indonesia (Diknas 2004, 2006, 2013).

Berdasarkan Kurikulum Tingkat Satuan Pendidikan (Diknas, 2006) menjelaskan bahwa kegiatan pembelajaran menulis karangan argumentasi berada di jenjang SMA kelas X. Materi menulis karangan argumentasi menjadi salah satu kompetensi yang harus dikuasai oleh setiap siswa. Pembelajaran menulis tidak semata-mata hanya bertujuan agar peserta didik mampu menulis saja, namun juga bertujuan untuk memberikan pengalaman secara langsung yang berkaitan dengan kehidupan nyata.Argumentasi adalah suatu bentuk retorika yang berusaha untuk mempengaruhi sikap dan pendapat orang lain, agar mereka percaya dan akhirnya bertindak sesuai dengan apa yang diinginkan oleh penulis atau pembicara (Keraf, 2007: 22). Melalui karangan argumentasi penulis menuangkan seluruh ide dan gagasan mereka, bahkan dapat juga berupa kritik yang didukung oleh berbagai data dan fakta yang dicari oleh penulis untuk mendukung suatu pendapat.

Jauhari (2013: 64) berpendapat bahwa argumentasi adalah salah satu jenis karangan dari hasil buah pikiran yang disampaikan ke- 
pada pembaca agar diterima atau dipercaya oleh pembaca.Karangan argumentasi bertujuan untuk membuktikan kebenaran suatu pendapat atau kesimpulan dengan data-data berupa fakta sebagai alasan. Dalam karangan argumentasi pengarang mengharapkan pembenaran pendapatnya dari pembaca (Kristiyani, 2012: 100). Adanya unsur opini, data, dan fakta penyokong opini tersebut.

Kegiatan pembelajaran menulis karangan argumentasi memerlukan beberapa tahapan yang harus dilalui oleh peserta didik. Hal ini dikarenakan dalam menulis karangan argumentasi peserta didik harus menggunakan segala data yang dapat mendukung pendapat mereka mengenai fenomena yang diangkat menjadi sebuah tulisan. Kompetensi menulis argumentasi dapat bermanfaat untuk melatih siswa dalam mengungkapkan pendapat, gagasan, dan ide-ide berdasarkan fakta secara logis dan sistematis. Apabila pemikiran logis dan sistematis ini dapat dilakukan oleh siswa, hal itu diharapkan dapat berpengaruh positif pada sudut pandang, pola pikir, dan tindakan mereka dalam menanggapi sebuah permasalahan. Serta dapat memberikan solusi untuk memecahkan masalah tersebut, baik yang bersifat sederhana maupun yang bersifat kompleks dalam menghadapi tantangan zaman.

Karangan argumentasi adalah suatu jenis karangan yang berisikan pendapat, kritik, ide-ide ataupun gagasan yang berdasarkan pada data dan fakta. Karangan argumentasi menuntut pemikiran yang kritis dan menggunakan datadata yang dapat digunakan siswa dalam menyampaikan pendapat mereka. Berpikir kritis, kreatif, dan pencarian data-data akan membuat siswa lebih selektif dan aktif dalam mencari fakta-fakta yang akan mereka gunakan untuk menanggapi sebuah permasalahan yang berada dikehidupan mereka.

Suatu pendekatan diperlukan guna meningkatkan kemampuan siswa dalam menulis karangan argumentasi. Selain pendekatan berbasis produk yang selanjutnya disebut pendekatan konvensional dalam penelitian ini.Ada pula pendekatan lain yang diharapkan mampu mengatasi permasalah yang dialami oleh siswa di kelas. Pendekatan yang ditawarkan adalah pendekatan proses dan pendekatan genre. Pendekatan proses dan pendekatan genre jarang digunakan oleh guru di Indonesia dalam kegiatan pembelajaran menulis karangan argumentasi.Oleh karena itu, penggunaan kedua pendekatan tersebut haruslah dibuktikan keefektifannya. Kedua pendekatan ini diharapkan mampu mengatasi permasalahan yang dialami oleh para siswa dalam pembelajaran menulis karangan argumentasi. Selama ini belum diketahui mengenai keefektifan pendekatan proses dan pendekatan genre dalam kegiatan pembelajaran menulis karangan argumentasi di SMA kelas X semester 1 .

Berdasarkan paparan di atas perlu adanya penelitian yang sungguh-sungguh terhadap keefektifan penggunaan pendekatan genre dalam pembelajaran menulis karangan argumentasi. Oleh karena itu, rumusan masalah dalam penelitian ini adalah: (1) adakah perbedaan keefektifan penggunaan pendekatan proses dan pendekatan genre dalam pembelajaran menulis karangan argumentasi; (2) adakah perbedaan keefektifan pendekatan proses,pendekatan genre, dan pendekatan konvensional dalam pembelajaran menulis karangan argumentasi siswa SMA. Tujuan dari penelitian ini adalah: (1) untuk mengetahui perbedaan keefektifan penggunaan pendekatan proses dan pendekatan genre; (2) untuk mengetahui perbedaan keefektifan dalam penggunaan pendekatan proses, pendekatan genre, dan pendekatan konvensional padapembelajaran menulis karangan argumentasi pada siswa SMA kelas X di Kabupaten Banyumas.

Pendekatan proses dikenal pertama kali pada tahun 1963 yang diperkenalkan pada pertemuan Conference of College Composition and Comunication (Clark, 2003: 5). Pendekatan proses adalah pendekatan yang digunakan dalam pembelajaran menulis dan menetapkan bahwa dalam kegiatan menulis membutuhkan proses atau langkah-langkah yang cukup panjang untuk menghasilkan sebuah tulisan yang memiliki kualitas dan layak untuk dibaca oleh orang lain. Pendapat ini sejalan dengan pernyataan Tompkins (2010: 51) bahwa kegiatan pembelajaran menulis dengan pendekatan proses (process approach) haruslah melewati beberapa tahapan yang harus dilakukan oleh siswa yang akan menentukan kualitas tulisan tersebut. Pendekatan proses berfokus pada langkah-langkah kerja 
penulisan, dan fokus pada proses kognitif yang berpusat pada aktivitas menulis. Pendekatan proses sudah banyak sekali digunakan oleh para guru di Amerika dalam pembelajaran menulis karangan.

Pendekatan proses cenderung lebih fokus pada kegiatan yang bervariasi yang mempromosikan pembangunan dan pengembangan bahasa (Hasan \& Mohd. Moniruzzaman, 2010: 77). Pada dasarnya pendekatan proses berokus pada suatu proses berjalan melalui saat menulis termasuk menghasilkan ide atau gagasan, memutuskan ide yang ingin ditulis, dan menggunakan media bahasa untuk mengungkapkan gagasan (Grosmmann, 2009). Pendekatan proses pada pembelajaran menulis menekankan penulis sebagai produsen independen teks, tetapi lebih jauh lagi untuk mengatasi masalah yang selalu timbul dalam pembelajaran menulis, guru haruslah membantu peserta didik melakukan tugasmenulis. Berbagai perwuju dan dari perspektif ini yang konsisten dalam mengenali proses kognitif dasar sebagai pusat kegiatan menulis,dan menekankan kebutuhan untuk mengembangkan kemampuan siswa dalam merencanakan, menentukan masalah,retorika, mengusulkan,dan mengevaluasi untuk mendapatkan solusi (Hyland, 2004: 11).

Pendekatan proses memperlakukan menulis bukan sebagai produk selesai tetapi sebagai suatu proses. Pendekatan iniber fokus pada siswa dalam pelajaranmenulis, danguruhanya bertindak sebagai pemandu. Pendekatan proses dalam pembelajaran menulis melibatkan kegiatan yang terjadiselama produksi teks (Bayat, 2014). Richards (dalam Mourssi, 2013: 731) mendefinisikan menulis dengan pendekatan proses adalah sebagai pendekatan yang menempatkan penekanan pada proses penyusunan, di mana penulis membuat alat bantu, seperti perencanaan, penyusunan dan revisi. Pembelajaran menulis dengan pendekatan proses menekankan pada pentingnya langkah-langkah yang berulang-ulang (recursive) mencangkup kegiatan pramenulis, menulis draf, mengevaluasi, dan merevisi (Nordin \& Mohammad, 2006: 75). Terdapat lima tahap atau langkah-langkah yang harus dilakukan oleh guru untuk mengajarkan materi menulis di kelas. Kelima tahapan pendekatan proses menurut Tompkins adalah pramenulis, penyusunan, revisi, perbaikan, dan penerbitan (Tompkins, 2010: 52).

Pendekatan genre pertama kali dikenalkan oleh M.A.K. Halliday pada tahun 1980-an di Australia (Knapp, 2005: 8). Pendekatan genre (genre approach) lebih menekankan pada jenis tulisan, tujuan penulisan, penyusunan elemen teks, dan penggunaan tata bahasa yang sesuai dengan tujuan penulisan. Pendekatan genre juga berfokus pada pembaca, jenis teks, dan fungsi teks itu sendiri. Pendekatan genre telah banyak diterapkan di berbagai sekolah di Australia, dan menjadi salah satu pendekatan yang telah terbukti sangat efektif dalam pembelajaran menulis di Australia.

Wang (2013) menjelaskan bahwa pendekatan genre merupakan pendekatan yang digunakan dalam pembelajaran menulis yang terbaru, membutuhkan waktu menulis yang dominan lama, dan menganggap konteks, hubungan penulis dengan pembaca, serta tujuanpada waktu yang sama. Martin (1997: 23) mendefinisikan pendekatan genre sebagai pendekatan yang berorientasi pada tujuan yang disatukan dengan proses sosial. Genre adalah proses sosial karena anggota budaya berinteraksi untuk mencapai tujuan, karena mereka telah berevolusi untuk mencapai hal-hal yang diinginkan dan diwujudkan berdasarkan makna yang dibuat penulis dalam langkah-langkah yang biasanya membutuhkan lebih dari satu langkah untuk mencapai tujuan. Dengan menetapkan tahapan diharapkan pendekatan genre dapat membantu guru memberikan pembelajaran menulis kepada para siswa dengan tata bahasa secara eksplisit, di dalam dan di luar kalimat, untuk menghasilkan teks yang tampak baik dan sesuai dengan pembaca.

Pendekatan genre dikembangkan untuk menanggapi kritik dari keterbatasan pendekatan proses yang meninggalkan siswa untuk menemukan struktur teks berulang melalui eksperimen dan eksplorasi. Paltridge (2007: 931) juga mengklaim bahwa banyak konvensi menulis akan tetap buram bagi peserta didik, kecuali guru membawa bentuk-bentuk dan pola penggunaan bahasa untuk menyadarkan mereka. Sejak penyusunan, perencanaan dan editing hanya bagian dari seluruh proses menulis 
yang terdapat pada pendekatan proses dirasa kurangan, karena tidak memberikan para siswa pedoman yang jelas dalam membangun berbagai jenis teks tertulis.

Pendekatan berbasis genre yang sangat menekankan pada hubungan antara jenis teks dan konteks (Luu, 2011: 121). Dalam melakukannya, bertujuan untuk membantu siswa menjadi efektif dalam lingkungan akademik dan profesional dalam masyarakat yang lebih luas (Luu, 2011: 121). Pendekatan berbasis genre yang menekankan pentingnya menjelajahi konteks sosial dan budaya dalam penggunaan bahasa pada suatu tulisan. Konteksnya memutuskan tujuan teks, struktur keseluruhan teks dalam hal fitur bahasa dalam teks, sering dalam bentuk konvensi linguistik (Luu, 2011: 121). Pendekatan genre berpendapat bahwa siswa hanya dapat menghasilkan komposisi yang akan berhasil diterima oleh komunitas wacana bahasa khususnya setelah mereka mengambil suatu konteks ke dalam tulisan mereka (Luu, 2011). Menggarisbawahi bahwa menulis adalah aktivitas sosial. Menurut teori ini, pengetahuan terbaik dibangun ketika peserta didik berkolaborasi, saling mendukung untuk mendorong cara-cara baru untuk membentuk, membangun dan merefleksikan pengetahuan baru. Dalam hal ini, interaksi sosial dan partisipasi anggota kelompok memainkan peran kunci dalam mengembangkan pengetahuan baru. Di kelas menulis, siswa didorong untuk berpartisipasi dalam kegiatan yang berarti pertukaran dan negosiasi dengan rekan-rekan dan guru. Belajar menulis dengan cara ini, diyakini bisa menghapus perasaan isolasi yang banyak mengganggu peserta didik saat menulis dan pada saat yang sama membantu siswa mendapatkan bantuan positif tentang pengetahuan linguistik, konten dan ide-ide dalam penyusunan teks (Luu, 2011: 121).

Pendekatan genre berkaitan dengan peserta didik menggunakan pola bahasa untuk mencapai koheren dalam karangan yang mereka tulis. Keyakinan utamanya adalah bahwa "kita tidak hanya menulis, kita menulis sesuatu untuk mencapai beberapa tujuan" (Hyland, 2004: 18). Dalam pendekatan ini, penulis (peserta didik) diminta untuk mengambil tujuan sosial keseluruhan teks dan dipertimbangkan saat menulis teks
(Luu, 2011: 121). Knapp \& Watkins (2005: 15) menyajikan tahapan menulis dengan pendekatan genre yang terdiri dari tiga tahapan utama yaitu modeling a text, joint construction of the text, dan independent counstruction of the text.

Telah banyak penelitian mengenai penerapan pendekata genre dalam kegiatan pembelajaran menulis. Penelitian yang membuktikan pendekatan genre efektif dalam pembelajaran menulis, yakni penelitian yang dilakukan oleh Hyejeong (2012: 1). Penelitian yang dilakukan oleh Hyejeong (2012: 1), menjelaskan bahwa penelitian mengenai implementasi pendekatan genre di kelas ESL budaya dan bahasa yang berbeda, di sebuah sekolah dasar metropolitan di Australia Selatan. Hasil penelitian menunjukkan bahwa proses keaktifan guru pada tahap awal dari siklus menguntungkan siswa membuat teks yang diatur berbeda untuk tujuan komunikatif yang berbeda pula. Selain itu, tingkat kepercayaan siswa meningkat dan pendekatan genre mendorong sikap positif terhadap kegiatan menulis.

\section{METODE}

Jenis penelitian ini adalah kuasi eksperimen. Desain ekperimen yang digunakan adalah rendomized pre-tes-posttest control group design. Terdapat tiga kelompok, yaitu dua kelompok eksperimen dan satu kelompok kontrol. Penelitian dilakukan pada siswa SMA Negeri kelas X di Kabupaten Banyumas. Populasi dalam penelitian adalah seluruh SMA Negeri yang di Kabupaten Banyumas. Jumlah SMA Negeri, yaitu 14 sekolah. Teknik pengambilan sampel yang digunakan adalah teknik sampel acak berlapis (multistage random sampling). Dari hasil pengambilan sampel, terpilihlah kelas X-8 SMA N 1 Baturraden sebagai kelompok eksperimen 1, X-9 SMA N 1 Sokaraja sebagai kelompok eksperimen 2, dan kelas X-6 SMA N 3 Purwokerto sebagai kelas kontrol.

Teknik pengumpulan data yang digunakan adalah dalam bentuk tes. Validitas instrumen dalam bentuk tes menulis karangan argumentasi yang diukur menggunakan lembar penilaian menulis karangan argumentasi. Pengujian kadar validitas instrumen menggunakan uji validitas isi menggunakan peran para ahli (expert judgement). Uji reliabilitas dilakukan 
dengan menggunakan rumus Alpha Cronbach. Teknik analisis data yang digunakan adalah uji-t dan ujiAnava satu jalur. Dalam melakukan uji-t dan uji statistik Anava satu jalur, data yang akan dianalisis harus memenuhi kriteria, yaitu (1) normalitas, dan (2) homogenitas.

\section{HASIL DAN PEMBAHASAN}

Kelas X-8 SMAN 1 Baturraden terpilih sebagai kelompok eksperimen 1, X-9 SMA N 1 Sokaraja terpilih menjadi kelompok eksperimen 2, dan kelas X-6 SMAN 3 Purwokerto terpilih menjadi kelompok kontrol. Pada kelompok eksperimen 1 menggunakan pendekatan proses, kelompok eksperimen 2 menggunakan pendekatan genre dalam pembelajaran menulis karangan argumentasi. Kelompok kontrol menggunakan pendekatan konvensional Sebelum melakukan analisis data, langkah pertama yang harus dilakukan yakni uji prasyarat analisis, yakni dengan menguji data prates guna mencari normalitas dan homogenitas.

Uji normalitas dilakukan berdasarkan data prates yang dihasilklan oleh kelompok eksperimen dan kelompok kontrol. Dilakukan dengan tujuan untuk mengetahui sebaran data, apakah berdistibusi normal atau tidak. Uji normalitas yang dilakukan terhadap skor menulis karangan argumentasi berupa data prates yang dilakukan menggunakan uji kolmogorovsmirnov dengan taraf signifikan $(\alpha=0,05)$. Menguji normalitas suatu data dapat dilakukan dengan melihat kaidah signifikasi $(p)$. Asumsi uji normalitas, yaitu jika skor $(p) \geq 0,05$, maka data berdistribusi normal. Jika skor $(p) \leq 0,05$, maka data tidak berdistribusi normal. Berdasarkan hasil uji asumsi normalitas data prates menunjukkan bahwa sampel yang digunakan dalam penelitian ini berdistribusi normal, yaitu $p \geq 0,05$.Kelompok eksperimen 1 memperoleh skor $p$ sebesar 0,427 , kelompok eksperimen 2 memperoleh skor $p$ sebesar 0,199 , dan kelompok kontrol memeroleh skor $p$ sebesar 0,496. Tahap selanjutnya adalah melakukan uji homogenitas data prates. Uji homogentitas memiliki ketentuan bahwa semua data atau kelompok yang digunakan dalam penelitian haruslah dalam keadaan yang homogen. Uji homogentas dilakukan dengan menggunakan program SPSS versi 21.00 yang memperhatikan skor pada bagian Lavene statistic. Untuk mengetahui data tersebut homogen atau tidak dapat dilihat dari skor signifikasi $(p)$ yang didapatkan. Asumsi uji homogenitas data prates, yaitu jika $p \geq 0,05$ maka data tersebut bersifat homogen atau sama, dan jika skor $p \leq 0,05$ maka data tersebut bersifat heterogen. Dari hasil statistiklevene diperoleh sig sebesar 0,085, skor tersebut menunjukkan bahwa skor $p \geq 0,05$. Dapat disimpulkan pada taraf signifikasi 0,05 , semua kelompok yang digunakan dalam penelitian memiliki variasi kelompok yang sama.

Selanjutnya,dilakukan tahap perlakuan. Pada tahap perlakuan penelitian dilaksanakan selama 6 kali pertemuan pada masing-masing kelas. Setelah melakukan prates dan perlakuan pada masing-masing kelas penelitian, tahap selanjutnya adalah melakukan tes akhir guna mengetahui keefektifan pendekatan proses, pendekatan genre dan pendekatan konvensional. Langkah selanjutnya adalah membandingkan tingkat keefektifan pada ketiga pendekatan yang digunakan dalam penelitian.

\section{Tabel 1. Data skor rata-rata}

\begin{tabular}{clcc}
\hline \multirow{2}{*}{ No } & \multirow{2}{*}{ Kelas } & \multicolumn{2}{c}{ Nilai Rata-rata } \\
\cline { 3 - 4 } & & Pra-tes & Pasca-tes \\
\hline 1 & Kelas Eksperimen 1 & 65,30 & 74,50 \\
2 & Kelas Eksperimen 2 & 65,17 & 76,00 \\
3 & Kelas Kontrol & 64,23 & 73,00 \\
\hline
\end{tabular}

Berdasarkan tabel di atas menunjukan bahwa masing-masing kelas yang digunakan dalam penelitian mengalami peningkatan skor rata-rata, hal ini membuktikan bahwa setiap pendekatan yang digunakan dalam pembelajaran menulis karangan argumentasi efektif, hanya saja perlu adanya perhitungan dan analisis yang mendalam untuk mendapatkan pendekatan yang paling efektif dalam pembelajaran menulis karangan argumentasi.

Hasil uji-t terhadap data pascates kelompok eksperimen 1 dan 2 menghasilkan skor $\mathrm{t}$ sebesar 3,259 dan skor signifikasi sebesar 0,002. Berdasarkan hasil tersebut dapat disimpulakan bahwa ada perbedaan yang signifikan terhadap penggunaan pendekatan proses dan pendekatan genre dalam pembelajaran menulis karangan argumentasi siswa SMA Negeri di Kabupaten 
banyumas. Uji Anava terhadap skor pascates kelompok eksperimen 1, eksperimen 2, dan kelompok kontrol menghasilkan skor F sebesar 160, 147 dengan skor signifikasi sebesar 0,000, skor tersebut lebih besar dibandingkan dengan skor $\mathrm{F}_{\text {tabel }}$, maka dapat disimpulkan bahwa ada perbedaan yang signifikan terhadap penggunaan pendekatan proses, genre dan konvensional. Selanjutnya, melakukan uji Scheffe untuk mengetahui secara rinci pendekatan mana yang paling berbeda dan efektif dalam pembelajaran menulis karangan argumentasi.

Melihat hasil dari ketiga uji Scheffe yang telah dilakukan, didapatkan kesimpulan bahwa adanya tingkat keefektifan yang berbeda pada ketiga pendekatan tersebut. Keefektifan pada ketiga pendekatan yang digunakan dapat diurutkan dari yang tinggi hingga yang rendah. Pendekatan genre menempati urutan pertama dalam tingkat kefektifan pada pembelajaran menulis karangan argumentasi. Pendekatan proses berada pada tingkat kedua setelah pendekatan genre. Pendekatan konvensional yang selalu guru gunakan menempati posisi ketiga. Dilihat secara keseluruhan pendekatan genre merupakan pendekatan yang paling efektif yang dapat digunakan oleh para guru dalam pembelajaran menulis karangan argumentasi pada siswa SMA kelas X di Kabupaten Banyumas.

Pendekatan proses pertama kali dikenalkan pada pertemuan Conference of college composition and comunication pada tahun 1963 di Amerika (Clark, 2008: 5). Pada konferensi tersebut menjelaskan ada pembaharuan minat terhadap retorika dan komposisi dalam kegiatan menulis. Pendekatan proses pada forum tersebut menjadi sebuah area baru untuk bahan penelitian yang difokuskan pada pemahaman seseorang untuk belajar menulis. Hal tersebut menegaskan bahwa kegiatan menulis menjadi suatu proses yang berorientasi pada kegiatan menulis, penemuan strategi, dan kegiatan merevisi yang sekarang dianggap sebagai kegiatan yang penting dalam pembelajaran menulis di kelas (Clark, 2008: 5). Simpson (2014) mengakui bahwa menulis dengan pendekatan proses berkembang sebagai reaksi terhadap pendekatan produk dalam hal ini memenuhi kebutuhan untuk mencocokan proses penulisan yang melekat secara tertulis dalam bahasa ses- eorang berakibat memungkinkan peserta didik untuk mengekspresikan diri lebih baik sebagai individu. Pembelajaran menulis membutuhkan tahapan yang akan membantu peserta didik untuk menghasilkan suatu tulisan (Tompkins, 2010: 51).

Pendekatan prosesdalam kegiatan pembelajaran menulis menekankan penulis atau siswa sebagai produsen independen teks, namunlebih jauh lagi pendekatan proses digunakan untukmengatasi permasalahan yang selalu timbul dalam pembelajaran menulis. Berbagai perwuju dan dari perspektif yang konsisten dalam mengenali proses kognitif dasar sebagai pusat kegiatan menulis dan menekankan kebutuhan untuk mengembangkan kemampuan siswa dalam merencanakan, menentukan masalah, retorika, mengusulkan, dan mengevaluasi guna mendapatkan solusi (Hyland, 2004: 11).

Pendekatan proses memperlakukan hasil tulisan bukan sebagai produk selesai tetapi sebagai suatu proses. Pendekatan proses berfokus padasiswa dalam pelajaran menulis dan guru bertindak sebagai pemandu. Pendekatan proses dalam pembelajaran menulis melibatkan kegiatan yang terjadi selama produksi teks (Bayat, 2014). Mourssi (2013: 731) mendefinisikan menulis dengan pendekatan proses memberikan penekanan pada proses penyusunan dan penulis membuat alat bantu seperti perencanaan, mengatur, penyusunan dan merevisi tulisan mereka. Telah banyak penelitian yang mengidentifikasi beberapa kunci penting untuk menulis dengan baik. Contohnya pada penelitian yang dilakukan oleh Berkenkotter pada tahun 1982 yang membuktikan bahwa siswa diberi kesempatan untuk terlibat dalam kegiatan pramenulis secara langsung (Sasse \& Laura, 2003).

Pendekatan proses dalam pembelajaran menulis memungkinkan banyak waktu bagi siswa untuk berpikir tentang objek dan membuat revisi terhadap pemikiran awal.Penelitian lain yang pernah dilakukan oleh Haynes pada tahun 1978 menunjukkan bahwa kegiatan prapenulisan penting untuk dilakukan (Sasse \& Laura, 2003). Kerjasama yang dilakukan dengan rekan akan memberikan kesempatan yang mengarahkan siswa untuk merevisi tulisan mereka. Menggunakan pendekatan proses dalam kegiatan menulis memberikan peserta didik waktu yang cukup 
untuk merencanakan, merancangan, merevisi, dan memperbaiki tulisan. Seringkali kesalahan berada pada hasil dari pemeriksaan yang tidak memadai dan siswa harus meningkatkan kinerja hanya untuk mengedit tulisan (Sasse \& Laura, 2003).

Penelitian lain yang pernah dilakukan di Indonesia salah satunya, yaitu penelitian yang dilakukan oleh Windana (2010) yang berjudul Implementasi Pendekatan Proses Berbasis Lingkungan dalam Meningkatkan Kualitas Pembelajaran Menulis Siswa Kelas IV SD Negeri 1 Yehembang Kecamatan Mendoyo Kabupaten Jembrana. Hasil penelitian menjelaskan bahwa pendekatan proses berbasis lingkungan yang digunakan pada siswa kelas IV SD Negeri 1 Yehembang dalam pembelajaran menulis efektif. Dari hasil penggunaan pendekatan proses terhadap pembelajaran menulis pada tiap siklusnya mengalami peningkatan yang signifikan.

Ada pula penelitian lain yang dilakukan oleh Badar (2007) dalam penelitian yang berjudul Pengembangan Model Pembelajaran Pendekatan Proses untuk Meningkatkan Keterampilan Menulis Siswa SMP pada Mata Pelajaran Bahasa Sunda. Hasil penelitian membuktikan bahwa pembelajaran menulis pada mata pelajaran bahasa Sunda yang menggunakan pendekatan proses mampu meningkatkan aktivitas siswa selama pembelajaran dan pendekatan proses mampu membantu meningkatkan keterampilan menulis siswa.

Pendekatan proses memperlakukan semua kegiatan menulis sebagai tindakan kreatif yang membutuhkan waktu dan umpan balik positif. Sebuah proses penting dalam kegiatan penulisan yang dilakukan secara berulang-ulang. Penulis harus bolak-balik antara menyusun gagasan secara bersamaan, membaca ulang, dan menulis ulang pikiran-pikiran (merevisi). Kegiatan menulis yang baik memerlukan koordinasi yang kompleks antara perencanaan, penyusunan, dan ide-ide yang selanjutnya akan direvisi. Selain memberi penulis lebih banyak waktu untuk menulis, merenung, dan merevisi pikiran, menulis dengan pendekatan proses memungkinkan untuk berkolaborasi dengan berbagai data yang dapat digunakan sebagai pendukung dari tulisan para siswa. Itulah tujuan dari semua yang terdapat pada pendekatan proses dalam kegiatan pembelajaran menulis. Dalam penelitian ini pendekatan proses digunakan dalam pembelajaran menulis karangan argumentasi pada kelas eksperimen 1.

Berdasarkan hasil penelitian pendekatan proses yang digunakan pada kelas eksperimen 1 efektif dalam kegiatan pembelajaran menulis karangan argumentasi. Hal tersebut dibuktikan dari skor rata-rata kelas eksperimen 1 meningkat setelah menggunakan pendekatan proses selama pembelajaran menulis karangan argumentasi. Siswa lebih berfokus dalam mengikuti setiap tahapan dalam pembelajaran. Hasli karangan siswa setelah tahap pembelajaran mengalami perbaikan dan peningkatan dari segi pilihan kosakata, kelengkapan struktur karangan, dan kepaduan antarparagraf.

Pendekatan genre dalam pembelajaran menulis lahir sejak tahun 1980-an di Australia yang diprakarsai oleh ahli bahasa fungsional yakni Halliday (Kim, 2007; Knapp \& Watkins, 2005: 23). Genre dapat didefinisikan sebagai jenis teks (text type) yang berfungsi sebagai pola rujukan (frame of reference), sehingga suatu teks dapat dibuat dengan efektif. Efektif dari sisi ketepatan tujuan, pemilihan, penyusunan teks (text elements), dan ketepatan dalam penggunaan tata bahasa (Pardiyono, 2007: 10). Wang (2013) menjelaskan bahwa pendekatangenre adalah pendekatan yang digunakan dalam pembelajaran menulis yang terbaru. Menulis membutuhkan waktu yang dominan lama, menganggap konteks, hubungan penulis dengan pembaca, serta tujuan pada waktu yang sama.

Pendekatan genre dalam pembelajaran menulis menekankan kepada siswa mengenai berbagai jenis tulisan yang berkaitan dengan keadaan sosial. Di sisi lain pendekatan genre lebih memfokuskan pada pembaca, dan tulisan perlu mengikuti konvensi agar berhasil diterima oleh para pembaca (Kim, 2005). Pada pendekatan genre pengetahuan bahasa melekat erat pada tujuan sosial dan lebih fokus pada sudut pandang pembaca dari pada penulis (Kim, 2007). Kim (2005) mendefinisikan pendekatan genre sebagai pendekatan yang berorientasi pada tujuan disatukan dengan proses sosial. Genre adalah proses sosial karena anggota budaya berinteraksi untuk mencapai tujuan yang diinginkan dan diwujudkan berdasarkan makna 
yang dibuat penulis dalam langkah-langkah. Diharapkan pendekatan genre dapat membantu guru memberikan pembelajaran menulis kepada para siswa dengan tata bahasa secara eksplisit dan menghasilkan teks yang sesuai dengan pembaca.

Wang (2013) menjelaskan bahwa pendekatan genre efektif untuk digunakan dalam pembelajaran menulis. Memberikan manfaat kepada peserta didik yang berkaitan dengan aspek perkembangan konteks dan organisasi retorika yang lebih dominan dalam ketelitian bahasa.Penggunaan pendekatan genre dalam pembelajaran menulis berfokus pada teks secara luas dan bahasa dipandang sebagai suatu konteks yang menyiratkan berbagai kendala sosial. Penulis memiliki tujuan dan niat tertentu yang berhubungan dengan pembaca, informasi tertentu disampaikan dalam bentuk teks. Pendekatan genre berorientasi pada penggabungan wacana dan aspek kontekstual penggunaan bahasa.

Berbagai penelitian telah dilakukan guna membuktikan keefektifan pendekatan genre dalam pembelajaran menulis karangan. Salah satu penelitian mengenai penggunaan pendekatan genre dalam pembelajaran menulis yang dilakukan oleh peneliti Indonesia, yaitu penelitian yang dilakukan Fauziah (2014) yang berjudul Pendekatan Berbasis Genre dalam Pembelajaran Menulis Teks Laporan. Hasil penelitian menunjukkan bahwa penggunaan pendekatan berbasis genre efektif dalam pembelajaran menulis teks laporan. Pendekatan genre yang digunakan dalam pembelajarana menulis teks laporan membantu siswa dalam meningkatkan kemampuan menulis. Terdapatnya penggunaan bahasa dan struktur yang sistematis pada hasil tulisan para siswa.

Penelitian lain yang berkaitan dengan penggunaan pendekatan genre dalam pembelajaran menulis dilakukan oleh Anggaira (2012) dalam tesisinya yang berjudul Penggunaan Pendekatan Berbasis Genre untuk Meningkatkan Kompetensi Menulis Bahasa Inggris Siswa Kelas VIII A SMP N 3 Metro Lampung Tahun Ajaran 2011/2012. Hasil dari penelitian menunjukkan bahwa pada setiap tahapan terjadi peningkatan. Pada tahapan building knowledge of field kemampuan siswa untuk megungkapkan kosakata meningkat, pada tahapan modeling of text siswa lebih mudah memahami penjelasan guru tentang genre yang dipelajari, pada tahapan joint construction of text siswa sudah mampu mengadakan interaksi dengan teman sekelompoknya, dan pada tahapan independent construction of text siswa telah mampu membuat karangan tanpa bantuan dari guru dan teman. Dapat disimpulkan bahwa pendekatan berbasis genremampu meningkatkan kompetensi menulis siswa.

Dalam penerapan pendekatan genre pada pembelajaran menulis karangan juga memiliki langkah-langkah yang harus dilakukan oleh peserta didik guna mendapatkan tulisan yang baik. Langkah-langkah tersebut, yaitu tulisan harus sesuai dengan konteks, fungsi, dan tujuan dari teks yang ditulisnya. Yan (2005) menjelaskan langkah-langkah dalam pembelajaran menulis dengan menggunakan pendekatan genre meliputi tahapan menyajikan target genre tulisan tertentu sebagai model bagi siswa, penyusunan teks bersama-sama, dan penyusunan teks secara mandiri (Yan, 2005).

Knapp \& Watkins (2005: 75-78) menyajikan tahapan menulis dengan pendekatan genre yang terdiri dari tiga tahapan utama, yaitu modeling a text, joint construction of the text, dan independent counstruction of the text. Penelitian ini menggunakan pendekatan genre dengan langkah-langkah yang digagas oleh Knapp \& Watkins.Berdasarkan hasil analisis pada data pascates kelompok eksperimen 1 dan 2 terbukti bahwa ada perbedaan keefektifan terhadap penggunaan pendekatan proses dan genre dalam pembelajaran menulis karangan argumentasi siswa SMA Negeri di Kabupaten Banyumas. Pendekatan proses dan genre memiliki kelebihan masing-masing dalam pembelajaran menulis karangan argumentasi. Pendekatan proses membuat siswa berfokus pada tahapan penulisan. Pendekatan genre membuat siswa berfokus pada tahapan penulisan, tujuan menulis, struktur karangan, jenis karangan, dan pembaca.

Berdasarkan hasil perhitungan yang menggunakan teknik uji Anava dan dilanjutkan uji scheffe dengan bantuan SPSS versi 21 terhadap data pascates kelompok eksperimen 1 yang menggunakan pendekatan proses, eksperimen 2 yang menggunakan pendekatan genre, dan 
kontrol yang menggunakan pendekatan yang biasa guru gunakan dalam pembelajaran menulis karangan argumentasi. Penggunaan pendekatan proses, pendekatan genre, dan pendekatan konvensional dalam pembelajaran menulis karangan argumentasi pada siswa SMA Negeri kelas $X$ dapat ditarik kesimpulan bahwa ada perbedaan keefektifan pada ketiga pendekatan tersebut.

Terbukti ada perbedaan keefektifan penggunaan pendekatan proses dengan pendekatan konvensional dalam pembelajaran menulis karangan argumentasi menguatkan bahwa kegiatan menulis tidak hanya menuntut hasil atau produk tulisan saja, namun kegiatan menulis membutuhkan suatu proses panjang untuk menghasilkan tulisan yang baik. Pendekatan proses dalam pembelajaran menulis karangan argumentasi menekankan penulis tidak hanya sebagai produsen teks, tetapi digunakan sebagai solusi untuk mengatasi masalah yang kerap terjadi di dalam kelas menulis karangan argumentasi. Dalam pembelajaran menulis karangan argumentasi siswa diberikan kesempatan untuk merancang dan memperbaiki tulisan mereka, sehingga dihasilkan tulisan yang memiliki kualitas yang baik.

Terbukti ada pendekatan proses efektif diterapkan dalam pembelajaran menulis karangan argumentasi sejalan dengan pendapat Mourssi (2013: 731) yang mendefinisikan menulis dengan menggunakan pendekatan proses adalah sebagai pendekatan yang menekanan pada tahap penyusunan, penulis membuat alat bantu seperti perencanaan, penyusunan, dan melakukan revisi sebagai tahap akhir. Kegiatan penulisan yang baik memerlukan koordinasi yang kompleks antara perencanaan, penyusunan, dan perbaikan terhadap ide-ide yang ingin dituangkan penulis. Pendekatan proses yang digunakan dalam penelitian berfokus pada kegiatan kelas yang menghasurkan peserta didik untuk mengikuti tahapan secara runtut. Pendekatan proses berupa tindakan interaktif yang dapat ditinjau, dievaluasi, dan direvisi bahkan sebelum teks selesai. Oleh karena itu, pendekatan proses lebih efektif dibandingkan dengan pendekatan konvensional dalam pembelajaran menulis karangan argumentasi.

Hasil analisis data pascates yang telah dilakukan membuktikan bahwa ada perbedaan yang signifikan antara penggunaan pendekatan genre dan pendekatan konvensional. Pendekatan genre lebih efektif digunakan dalam pembelajaran menulis karangan argumentasi dibandingkan dengan pendekatan konvensional yang guru gunakan dalam pembelajaran menulis karangan argumentasi. Keefektifan pendekatan genre juga dapat dilihat dari perbandingan skor hasil prates dan pascates pada kelas eksperimen 2 yang mengalami peningkatan dibandingkan dengan kelas kontrol yang menggunakan pendekatan konvensional. Hal tersebut dapat diartikan bahwa penggunaan pendekatan genre memiliki andil yang besar dalam pembelajaran menulis karangan argumentasi.

Keefektifan penggunaan pendekatan genre dibandingkan dengan konvensional dalam pembelajaran menulis karangan argumentasi menguatkan bahwa kegiatan menulis tidak hanya menuntut hasil atau produk tulisan, namun kegiatan menulis membutuhkan langkahlangkah yang sesuai dengan tujuan, konteks sosial, pemilihan kosakata, penggunaan bahasa, fokus pada pembaca, dan penyusunan karangan. Pendekatan genre pada pembelajaran menulis berfokus pada teks secara luas dan bahasa dipandang sebagai suatu konteks yang menyiratkan berbagai kendala sosial yang dipilih, beroperasi pada penulis, dan berfokus pada pembaca. Penulis memiliki tujuan dan niat tertentu yang berhubungan dengan pembaca, serta informasi tertentu untuk disampaikan dalam bentuk teks.

Pendekatan genre dalam pembelajaran menulis yang digunakan pada kelas ekperimen 2 lebih menekankan siswa untuk mengetahui berbagai jenis tulisan yang berkaitan dengan keadaan sosial. Hal tersebut sejalan dengan pendapat yang menyatakan bahwa pendekatan berbasis genre menekankan pada hubungan antara jenis teks dan konteks (Hyon, 1996: 693). Pendekatan genre yang digunakan pada kelas eksperimen 2 tidak terlepas dari orientasi bahwa sebuah teks memiliki tujuan yang berkaitan dengan keadaan sosial masyarakat.

Melihat skor rata-rata data pascates dari ketiga kelas yang digunakan dalam penelitian dapat disimpulkan bahwa terdapat tingkat keefektifan yang berbeda pada ketiga pendekatan tersebut dalam pembelajaran menulis karangan argumentasi. Keefektifan 
pada ketiga pendekatan yang digunakan dapat diurutkan sesuai dengan tingkan kefektifan dari yang tinggi hingga yang rendah. Pendekatan genre menempati urutan pertama dalam tingkat kefektifan pada pembelajaran menulis karangan argumentasi. Pendekatan proses berada pada urutan kedua. Pendekatan konvensional yang biasa guru gunakan menempati posisi ketiga dalam pembelajaran menulis karangan argumentasi siswa SMA Negeri kelas X di Kabupaten Banyumas.

Secara keseluruhan pendekatan genre menjadi pendekatan yang paling efektif dan dapat sebagai pendekatan alternatif untuk digunakan guru dalam pembelajaran menulis karangan argumentasi siswa SMA Negeri kelas X di Kabupaten Banyumas. Pendekatan genre lebih efektif dibandingkan dengan pendekatan proses dan pendekatan konvensional. Pendekatan genre tidak hanya menekankan pada tahapan menulis yang harus dilalui oleh peserta didik, namun juga mengharuskan siswa untuk menggunakan bahasanya secara benar, konsisten, dan karangan yang telah ditulis haruslah mengandung unsur tujuan. Pendekatan genre efektif dalam pembelajaran menulis karangan argumentasi dikarenakan karangan argumentasi memiliki struktur berbeda dari jenis karangan lainnya. Karangan argumentasi lebih menekankan konteks sosial yang didasari oleh data-data yang penulis dapatkan dari berbagai sumber, dan karangan argumentasi memiliki tujuan tertentu yang ingin disampaikan penulis kepada pembaca. Tidak dapat dipungkiri bahwa pendekatan proses juga efektif dalam pembelajaran menulis karangan argumentasi, namun pendekatan proses lebih menekankan pada tahapan yang harus dilalui peserta didik dalam pembelajaran menulis karangan tanpa memberikan perhatian pada jenis karangan, tujuan, penggunaan bahasa, dan hasil tulisan siswa.

Pendekatan genre dan pendekatan proses juga dapat digunakan secara bersama-sama sebagai alternatif bagi guru guna meningkatkan kemampuan menulis peserta didik terutama menulis karangan argumentasi. Kedua pendekatan ini telah teruji efektif dalam pembelajaran menulis karangan argumentasi.

\section{SIMPULAN}

Secara keseluruhan hasil perhitungan dan pembahasan, menunjukkan adanya tingkat keefektifan yang berbeda antara penerapan pendekatan proses, pendekatan genre, dan pendekatan konvensional, dalam peningkatan kompetensi menulis karangan argumentasi pada peserta didik SMA kelas X, di Kabupaten Banyumas. Memperhatikan hasil uji yang telah dijelaskan sebelumnya, dengan masingmasing skor signifikasi $(\mathrm{p}) \leq$ taraf signifikasi yang telah ditentukan, yakni sebesar 0,05 . Jadi dapat disimpulkan bahwa pendekatan genre lebih efektif dibandingkan dengan pendekatan proses dan pendekatan konvensional. Pendekatan genre dapat membantu para siswa dalam meningkatkan kompetensi menulis karangan argumentasi. Meskipun pendekatan proses berada pada tingkat kedua setelah pendekatan genre, pendekatan proses juga dapat digunakan sebagai alternatif dalam pembelajaran menulis karangan argumentasi, untuk peserta didik SMA kelas X, di Kabupaten Banyumas. Guru dapat menggunakan pendekatan genre, sebagai pendekatan alternatif dalam pembelajarana menulis karangan argumentasi sehingga dapat meningkatkan kemampuan menulis peserta didik.

\section{DAFTAR PUSTAKA}

Anggaira, Aria Septi. 2012. Penggunaan Pendekatan Berbasis Genre untuk Meningkatkan Kompetensi Menulis Bahasa Inggris Siswa Kelas VIII A SMP N 3 Metro, Lampung Tahun Ajaran 2011/2012. Tesis magister, tidak diterbitkan. Universitas Negeri Yogyakarta.

Badar, Akmal. 2007. Pengembangan Pembelajaran Pendekatan Proses untuk Meningkatkan Keterampilan Menulis Siswa SMP pada Mata Pelajaran Bahasa Sunda. Tesis magister, tidak diterbitkan. Universitas Pendidikan Indonesia.

Bayat, N. 2014. The Effect of the Process Writing Approach on Writing Success and Anxiety. Diakses pada 17 Maret 2015 dari http:// search.proquest.com/fulltextPDF/htm. 
Clark, Irene L. 2003. Conceots in Composition: Theory and Practice in the Teaching of Writing. New Jersey: Lawrence Erlbaum Associates.

Diknas. 2004. Kurikulum Berbasis Kompetensi untuk Sekolah Menengah Atas. Diakses pada 14 Maret 2015 dari http:// kemendikbud.go.id.

Diknas. 2006. Kurikulum Tingkat Satuan Pendidikan untuk Sekolah Menengah Atas. Diakses pada 14 Maret 2015 dari http:// kemendikbud.go.id.

Diknas. 2013. Kurikulum 2013 untuk Sekolah Menengah Atas. Diakses pada 14 Maret 2015 dari http://kemendikbud.go.id.

Fauziah, Anita Nurul. 2014. Pendekatan Berbasis Genre dalam Pembelajaran Menulis Teks Laporan. Tesis magister, tidak diterbitkan. Universitas Pendidikan Indonesia.

Hasan, Kamrul \& Moniruzzaman Akhand. 2010. Approaches To Writing In EFL/ESL Context: Balancing Product and Process in Writing Class at Tertiary Level. Diakses pada 1 Agustus 2015dari http:// nelta.org.my/e-jourlnal. htm.

Hyejeong, Ahn, 2012. Teaching Writing Skills Based on a Genre Approach to L2 Primary School Students: an Action Research. Diakses 15 Maret 2015 dari www.ccsenet.org/journal/.

Hyland, Ken. 2004. Second Language Writing. Cambridge: Cambridge University Press.

Hyon. 1996. Genre in Three Traditions: Implications for ESL [Versi elektronik]. TESOL Quarterly, 30, pp.693-732.

Jauhari, Heri. 2013. Terampil Mengarang. dari Persiapan Hingga Presentasi, dari Karangan Ilmiah Hingga Sastra. Bandung: Nuansa Cendikia.

Kemendiknas. 2011. Survei Internasional PIRLS. Diakses pada 12 September 2015 dari www.litbang.kemendikbud. go.id.

Keraf, Gorys. 2007. Argumentasi dan Narasi. Jakarta: Gramedia Pustaka Utama.

Kim, M.S. 2007. Genre-based approach to teaching writing. Diakses pada 1
Agustus 2015 dari http://www.hpu. edu-journal.com/ Genre.pdf.

Kim, Yanghee \& Jiyoung Kim. 2005. Teaching Korean University Writing Class: Balancing The Process and the Genre Approach. Diakses pada 1 Agustus 2015 dari http://www.asian-efl-journal. $\mathrm{com} / \mathrm{htm}$.

Knapp, P \& Watkins M. 2005. Genre, Text, Grammar. Sidney, NSW: University of New South Wales Press Ltd.

Kristiyani, Ary. 2012. Implementasi Kemampuan Calon Guru Bahasa Indonesia dalam Menilai Karangan Esai Argumentasi. Prosiding Seminar Nasional yang diselenggarakan oleh Fakultas Bahasa dan Seni UNY, tanggal 20 November 2012. Yogyakarta: Universitas Yogyakarta.

Martin, J. S. 1997. Analysizyng Genre: Fungtional Parameters, dalam (Cristie and Martin, eds) genre and institution: social process in the workplace and school. London: Continum.

Mourssi, Anwar. 2013. Theoretical and Practical Linguistic Shifting from Product/ Guided Writing to Process Writing and Recently to the Innovated Writing Process Approach In Teaching Writing for Second/Foreign Language Learners. Diakses pada 19 Maret 2015 dari http:// search.proquest.com/4.htm.

Nordin \& Mohammad. 2006. The Best of Two Approach: Process/Genre-Based Approach to Teaching Writing, the English Teacher. Diakses pada 1 April 2015 dari http://www.nelta.org.my//ET/.pdf.

Paltridge. 2007. . Approaches to Genre in ELT[Versi elektronik]. International Handbook ofEnglish Language Teaching, Vol. 15, 931-943.

Pardiyono. 2007. Pasti bisa! teaching genrebased writing: metode mengajar writing berbasis genre secara efektif. Yogyakarta: Andi Yogyakarta.

Sasse, Craig M \& Laura E.F. (2003). Developing Student Writers in Economics: a Process Writing Approach. Proquest educational journals, 4. Diambil pada 
tanggal 16 Maret 2015 dari http://proquest.com.

Simpson, Adam. 2014. A process Approach to Writing. Diakses pada 23 Maret 2015 dari www.developingteachers.com.

Luu, Tuan Trong, 2011. Teaching Writing Through Genre-Based Approach. Diakses 15 Maret 2015 BELT Journal di http://ojs.academypublisher.com/ articl.l

Tompkins, G.E. (2010). Literacy In The $21^{s t}$ Century a Balanced Approach. Fifth Edition. Boston: Allyn \& Bacon.

Wang,. Hunmei. (2013). A Study of Genre Approach in Efl Writing. Diakses pada 17 Maret 2015 darihttp:// search.proquest. com/4.htm
Windana, I Gusti Agung P. (2010). Implementasi Pendekatan Proses Berbasis Lingkungan dalam Meningkatkan Kualitas Pembelajaran Menulis Siswa Kelas IV SD Negeri 1 Yahembang, Kecamatan Mendoyo, Kabupaten Jembrana. Diambil pada tanggal 20 Juni 2015 dari http://pasca.undiksha.ac.id/php.

Yan, G. 2005. A Process Genre Model for Teaching Writing. English Teaching Forum. Diakses 15 Maret 2015 dari http:// exchanges.state.gov/htm. 